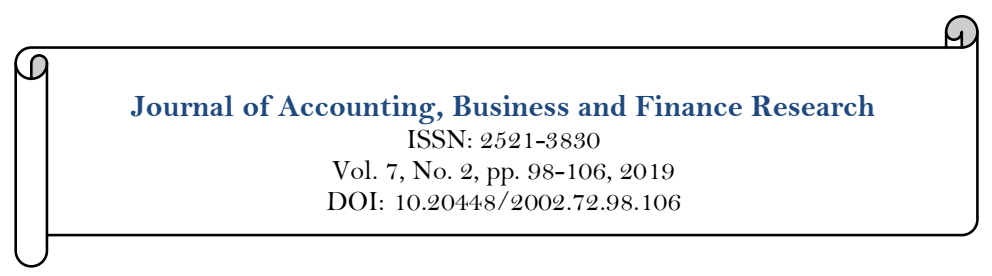

\title{
Does CEO Traits Influence Innovation? Evidence from the Kenya Banking Sector
}

\author{
Joel Kiplagat Tuwey ${ }^{2}$ \\ Vincent Ngeno ${ }^{2}$ \\ ${ }^{\prime}$ Department of Accounting and Finance, Moi University, Eldoret, Kenya. \\ Email:joeltuwey9@gmail.com \\ ${ }^{-}$Department of Agricultural Economics and Resource Management, Moi University, Eldoret, Kenya.
}

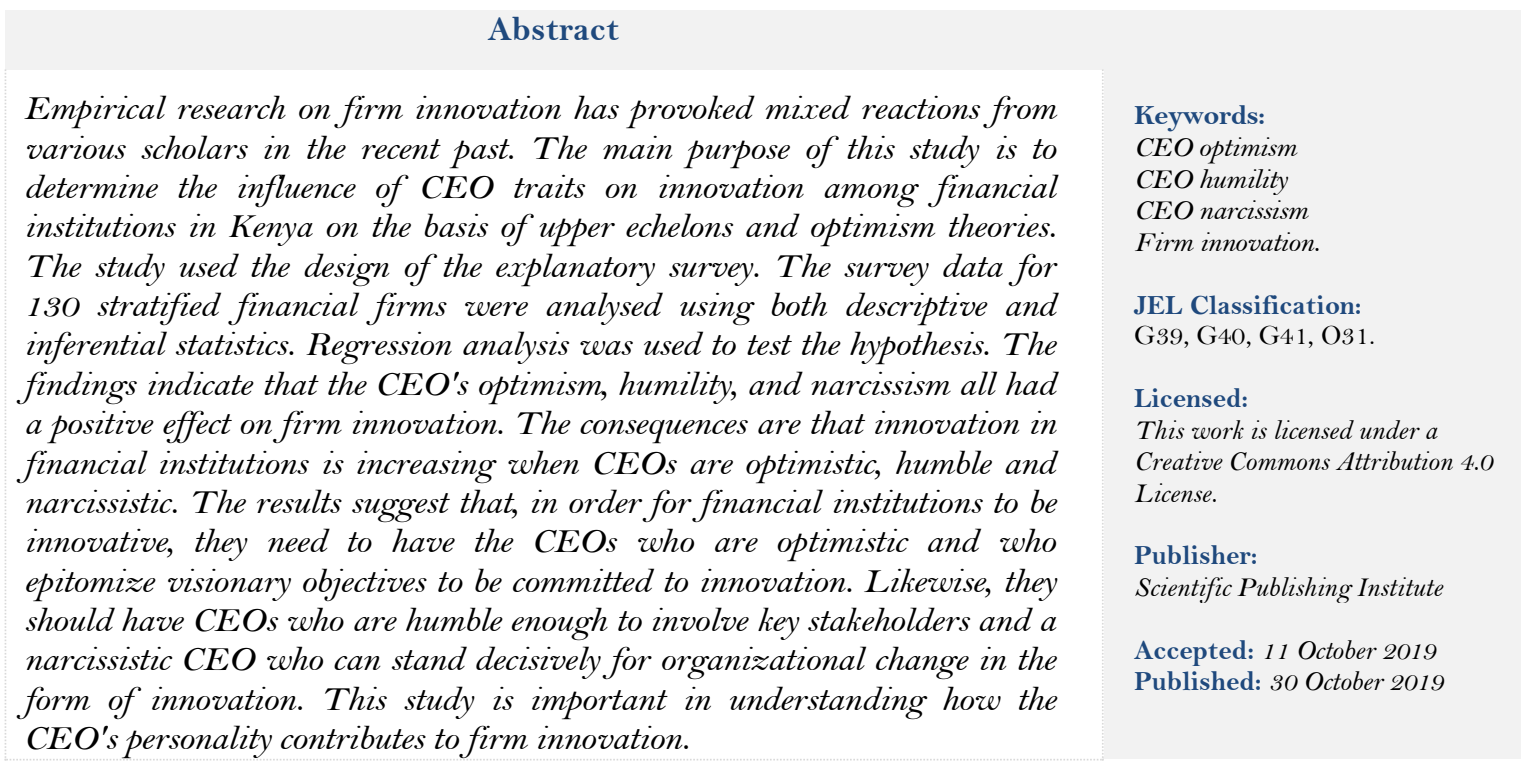

Funding: There was no funding for this research.

Competing Interests: There is no conflict of interest with regard to this paper.

\section{Introduction}

Firm's ability to thrive and compete in a volatile business environment in the 21 st century entirely depends on the ability to innovate. Innovations in organizations are the pillar for product development and the avenue for future revenue streams (Yar Hamidi \& Gabrielsson, 2014). It improves a firm's long term survival and competitive advantage (Ghosh, 2016); (Zhou, Gao, \& Zhao, 2017) as well as fulfilling the dynamic needs of diverse stakeholders. Firm innovation is a top agenda in the current business world and has become a valuable component in the strategic manual (Chakravarthy \& Yau, 2017); (Wang \& Dass, 2017) of diverse companies around the globe. According to Dobni, Klassen, and Nelson (2015) "firms that get it right eventually prove to be industry leaders, consistently create value for their products and services, improve their competitive advantage and financial performance." Therefore, innovation is a strategic function that corporate leadership has to pursue in order to foster success of the firm.

CEOs have a sizeable decision making authority and are essential for driving firm innovations (Zhang, Ou, Tsui, \& Wang, 2017). Although CEOs have a critical role in driving strategic functions such as innovation, more focus has been directed to their demographics (Chatterjee \& Hambrick, 2007) excluding their traits and yet CEOs play a key role in the company's strategic decision-making process. Further, of the studies that have investigated some traits has been done in developed countries compared to the less developed 
economies. Therefore, to fill this gap the study examines key traits of the CEO; optimism, humility and narcissism that are underexplored in literature especially in the financial sector in Kenya.

The financial sector in Kenya is dynamic and competitive, due to its innovative capabilities (Dutta, Lanvin, \& Wunsch-Vincent, 2018). Kenya is ranked 78th and 3rd in Sub-Saharan region after South Africa and Mauritius. Most innovations are in the finance sector which has partnered with mobile network operators such as Safaricom and Airtel to allow financial transactions to be effected using mobile phones. To legalize mobile money transfers the Central Bank of Kenya has since drafted laws are under the National Payment System Act of 2011 and 2014 respectively. Kenya is the first country to allow payment systems using mobile phones (Hughes \& Lonie, 2007).

The changes in the law to allow the use of mobile phones to execute financial transactions led to several other innovations since the launch of M-Pesa in 2007. These innovations include M-Kesho, M-Shwari, Eazzy banking, Kopesha, and Pesalink (Muthinja \& Chipeta, 2018). Statistics indicate that about 80\% of Kenyans use mobile banking services with M-PESA leading at nearly $70 \%$ of the total mobile money transfers (Lepoutre \& Oguntoye, 2018). These innovations allow customers to allows people to deposit, send and withdraw cash using their mobile handsets, pay insurance premiums, undertake point-of-sale transactions and payment of utility bills such as school fees, electricity and water bills, government services, retail outlets, and air ticketing among others (Chipeta \& Muthinja, 2018); (Lashitew, Van Tulder, \& Liasse, 2019). As such, consumers can access financial services conveniently by a click of a button at the comfort of their homes or work places without going to the bank (Jack \& Suri, 2011).

\section{Literature Review}

\subsection{Concept of Firm Innovation}

Earlier academicians described innovations as "creative destruction by an entrepreneur." In particular, researchers in various fields continue to revisit the concept of innovation (Damanpour \& Schneider, 2006) from a variety of perspectives, so there is no universal definition (Baregheh, Rowley, \& Sambrook, 2009). For example, innovation is conceived as "an idea, practice or object taken as new by an individual or an institution" (Wangs, 2009). It is also a unique way to create or improve a new product (Merton, 1995) or the ability to make real value for new or existing opportunities in response to varied expectations (Tidd \& Bessant, 2018) of the firm. New technology basically empowers firms to orchestrate with adjustments in the external environment, market, and customer requirements. Indeed, innovation is one of the key ingredients for the success of the firms although there are risks attached to its breakthrough. Innovation incorporates the efforts of different actors of the firm. However, it requires leadership that may influence and encourage employees to be innovative.

\subsection{Concept of CEO Traits}

Traits are complex, self-contained characteristics that consist of differing cognitive, motivational and behavioral components (Chatterjee \& Hambrick, 2007); (Ou et al., 2014). CEO traits are valuable and crucial for the management of companies. These traits explain why CEOs react differently to the same situation (Farrington, 2012). In the same way, it exposes CEOs persona or character (Haslam, 2007) to carry out their duties and responsibilities. CEO traits have captured the interests of the diverse scholars in an attempt to unearth their influence of various outcomes of the firm such as firm performance and investment among others (Galasso \& Simcoe, 2011); (Li \& Tang, 2010). Scholars have documented that leadership traits shapes how CEOs make decisions in different situations in the firm (Graham, Harvey, \& Puri, 2013). Further, previous literature indicates that CEOs perceive their influence on strategic decisions and outcomes of the firm (Gupta, Nadkarni, \& Mariam, 2018); (Zhang et al., 2017); (Ou et al., 2014); (Langabeer \& Yao, 2012). Hence, the study studied three important traits that influence decision making: CEO optimism, humility, and narcissism. These traits were hypothesized to influence firm innovation in Kenya's financial sector.

\subsection{Link between CEO Traits and Firm Innovation}

Drawing from the view of upper echelons, firm outcomes represent the values and cognitive foundations of powerful CEOs in the organization (Carpenter, Geletkanycz, \& Sanders, 2004); (Hambrick \& Mason, 1984). The theory further postulates that the perception of the CEOs on their firm environment affects the strategic alternatives they make. In essence, the personal attributes of the CEOs determine the aspects that they can "see" and what they see as informing the decisions they make about the strategic choices that eventually affect the bottom line of the organization. In this regard, CEOs have a substantial decision making power and are key drivers for firm activities. Generally, they are among the top corporate leaders who oversee the overall management and success of the firm. Accordingly, CEOs have a sizeable influence strategic decisions and outcomes such as innovations (Finkelstein, Cannella, Hambrick, \& Cannella, 2009); (Nyukorong \& Quisenberry, 2016); (Islam \& Zein, 2019). Importantly, their traits determine how firms perform (Hambricks, 2007). Indeed, drawing from existing literature certain traits make CEOs effective and efficient in executing their decision making authority. In other words, the power to make certain decisions such as to innovate stems from their character (Finkelstein, 1992). CEO traits, therefore, are important for strategic decision making and 
leadership because they may affect the way the CEOs perceive or interpret the volatility of the corporate environment (Hambricks, 2007). So the ability of the CEOs to understand the dynamics of the business environment based on their character are more likely to influence innovations. Although a number of traits have been explored in literature, the results are mixed and are confined to developed countries than emerging economies like Kenya. Some of the notable traits that have been tested empirically include CEO hubris (Li \& Tang, 2010), CEO overconfidence (Galasso \& Simcoe, 2011) and pilot CEOs (Sunder, Sunder, \& Zhang, 2017). This study investigated how important and yet underexplored traits such as CEO humility, narcissism and optimism influence innovations of firms in the finance sector of an emerging economy like Kenya.

\subsubsection{CEO Optimism and Firm Innovation}

CEO optimism is understood as a generalized view held by an individual that good things than bad will occur (Scheier, Carver, \& Bridges, 1994); (Scheier \& Carver, 1985). As such, it is a trait that promotes a person's assurance that positive outcomes may occur in the future. Indeed, optimists tend to be more resilient, have a positive view of the world and are action oriented (Carver \& Scheier, 2014); (Chiesi, Galli, Primi, Innocenti, \& Bonacchi, 2013). Optimists inspire others by sharing a positive vision and display a passionate interest to achieve that vision. Besides, they pursue goals even if frictions exist because they belief that good than bad is bound to happen to them in future (Trevelyan, 2008). Indeed, the role played by CEOs in firms is unique, more so their influence on strategic activities (Chatterjee \& Hambrick, 2011) and firm outcomes (Finkelstein et al., 2009). Studies have investigated this trait with regard to other firm outcomes not related to innovation in developed countries. For instance, existing studies observed that CEO optimism is positively associated with investment efficiency of a firm (Chen \& Lin, 2012). In essence, firms with CEOs who are optimistic tend to invest more than firms who's CEOs are pessimists. Other factors that CEO optimism enhances include corporate finance (Huang-Meier, Lambertides, \& Steeley, 2016) mergers and acquisition (Malmendier \& Tate, 2008) and firm valuation (Peterson, Walumbwa, Byron, \& Myrowitz, 2009). In view of these studies, CEO optimism adds value to the firm in terms of positive expectations.

Although CEO optimism has broadly been studied in finance, a few studies have explored its influence on innovation more so in an emerging economy. Additionally, of the few studies that have been studied, there is no consensus on how CEO optimism actually affect innovation in firms. For instance, the literature indicates that CEOs who are highly optimistic contributes more to return volatility, patents and patents citations and succeed in research and development activities (Hirshleifer, Low, \& Teoh, 2012). Equally, in other studies it has been found that CEOs who are overly optimistic are likely to engage in firm innovations more so in competitive industries (Galasso \& Simcoe, 2011). According to optimism theory (Scheier \& Carver, 1985) CEOs who are very optimistic tend to exude confidence that positive results are likely to occur and equally enthusiastic about risky and challenging strategic activities such as innovation. Thus, the study hypothesized that:

Hypothesis 1: CEO optimism positively affects firm innovation.

\subsubsection{CEO Humility and Firm Innovation}

Humility has rich social psychological, philosophical and theological roots (Davis et al., 2011). and is perceived as a human virtue that shows a stable trait among individuals (Vera \& Rodriguez-Lopez, 2004). This trait is linked to virtuous, moral, ethical, participative, empowering and servant leadership among executives (Hackett \& Wang, 2012). CEO humility is the CEO's orientation towards obtaining accurate self-awareness, giving credit to others when it is due and being open to self-improvement (Ou et al., 2014). In addition, CEO humility is the readiness to acknowledge that self-pride is not a prerequisite for achievement $(\mathrm{Xu}, \mathrm{Xu}$, Anderson, \& Caldwell, 2019) and as a disposition of self-accuracy, recognition of others' efforts and contributions, accepting one's own mistakes and ability to learn (Owens \& Hekman, 2016).

Being aware of themselves enable them to engage openly and seek advice from others, thus can adjust and capitalize on existing opportunities to make decisions efficiently (Argandona, 2015). CEOs who are humble tend to disregard personal interests but rather those that are critical to the firm (Nielsen, Marrone, \& Slay, 2010). As such, humble CEOs don't see themselves as superior to others but willing to share power with others (Morris, Brotheridge, \& Urbanski, 2005). Humility among CEOs assists in promoting justice and fairness and creating an atmosphere that discourages self-opportunistic behaviors (Owens \& Hekman, 2012).

Although humility is a key trait for CEOs who control increasingly dynamic and competitive firms (Friedman, Fischer, \& Schochet, 2017); (Frostenson, 2016), it has been largely ignored, more so in corporate strategic decision-making. Largely, literature shows that humility enhances competitiveness of the firm (Vera \& Rodriguez-Lopez, 2004) and is positively associated with firm performance, job satisfaction (Owens, Johnson, \& Mitchell, 2013) and effective leadership (Žiaran, 2015). In the recent past, a few scholars have attempted to investigate how $\mathrm{CEO}$ humility influence innovation in different firms, however, the focus has been directed to firms in developed countries than in developing markets. Moreover, the results could be different contextually since the legal and organizational cultures varies across firms in different countries. For example in a study done in the latest past, it was found that humility has no association with firm innovation (Zhang et al., 2017). 
In other words, CEOs who are humble may not have the vitality to engage and inspire other members in the firm to innovate this is because they are at disadvantage position where they can admit their mistakes thus creating potential criticisms either from other top managers or subordinates hence reducing the appetite to innovate. Upper echelons theory propose that psychological traits shape how CEOs process available information, make strategic decisions, allocate resources, lead employees and ultimate how firm can succeed (Finkelstein et al., 2009). Therefore, the tendency of humble CEOs to learn and improve is a motivation pursue greater interests than self (Ou et al., 2014), thus are strongly persuaded to engage in strategic decisions such as to innovate. Equally, since innovation is not an outright success, they acknowledge others' strengths (Owens et al., 2013) and recognize that firm innovation cannot be achieved single handed but through collective responsibility. In this study, we proposed that:

Hypothesis 2: CEO humility positively influences firm innovation.

\subsubsection{CEO Narcissism and Firm Innovation}

Narcissism is a concept comprising of superiority, desire for attention and arrogance (Campbell, Goodie, \& Foster, 2004). It is a trait linked to being self-centred, aggrandizing, dominant and interpersonally manipulative behaviour (Emmons, 1987). Hence, narcissistic leaders portray personalities such as dominance, self-love, and admiration, a sense of title and self-confidence, aggressive and hostile when criticized or confronted with negative feedback (Guedes, 2017). The sense of self-confidence and power of narcissist leaders often make them more appealing to follow and with their strong self-efficacy such leaders appear more effective and proactive in decision making (Chatterjee \& Hambrick, 2007). Existing works have shown that CEOs are not exceptional in portraying such traits (Zhang et al., 2017); (Germain, 2018).

Literature indicates that CEO narcissism affect firm outcomes (Gerstner, König, Enders, \& Hambrick, 2013). Chatterjee and Hambrick (2011) postulated that CEO narcissism positively relates to firm strategic dynamism. (Smith \& Webster, 2018) suggested that grandiose narcissism has an indirect effect on innovation through adaptability. Additionally, Goncalo, Flynn, and Kim (2010) hypothesized that narcissistic CEOs increase creativity among groups and traits such as dominance and extraversion of narcissistic CEOs enable firms to maneuver in volatile environments (Gupta \& Spangler, 2012).

These studies provide evidence that CEO narcissism influence firm outcomes in one way or another. However, with regard to innovation, few studies have been studied and the results are inconclusive. For example, (Zhang et al., 2017) found no association between CEO narcissism and firm innovation whereas (Kashmiri, Nicol, \& Arora, 2017) find that companies led by narcissistic CEOs are likely to unveil a higher rate of new product introductions and a higher proportion of radical innovations in their new product portfolios, but are also more likely to face product-harm crises. According to upper echelons theory, narcissism is an important personality aspect of CEOs that influences strategic decisions of the firm such as innovation (Chatterjee \& Hambrick, 2011); (Gerstner et al., 2013). In this case, a narcissistic CEO would devote much effort to innovation success to feel a sense of achievement and protect their public image (Bass \& Steidlmeier, 1999). Thus, we hypothesize that:

Hypothesis 3: CEO narcissism influences firm innovation.

Figure 1 below displays a conceptual framework that provides a logic justification of relations among variables in the study. The framework explains and justifies how CEO traits influence innovations.

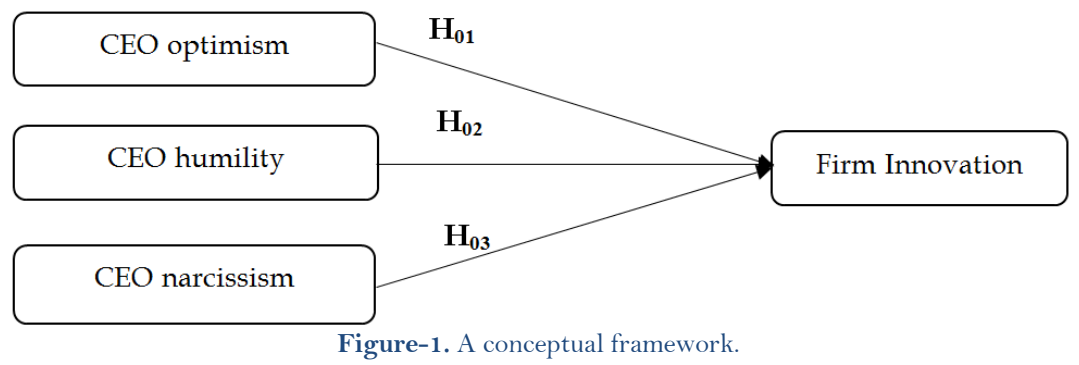

\section{Data and Methods}

The target population was 219 financial institutions in Kenya. Financial sector was appropriate because of an elaborate and sound framework of governance and the unique levels of innovations (Ngugi, Pelowski, \& Ogembo, 2010); (Daily, Dalton, \& Cannella, 2003; Giorgis Sahile, Tarus, \& Cheruiyot, 2015). The Yamane (1973) formula was used to arrive at a sample size of 183 firms as follows:

$n=\frac{\mathrm{N}}{1+\mathrm{N}_{\mathrm{e}^{2}}}$ Where: $\mathbf{n}=$ Sample size; $\mathbf{N}=$ Total population size; $\mathbf{e}=$ the error of Sampling (0.03).

$n=\frac{219}{1+219(0.03)^{2}}=183$ financial institutions. 
The primary data was collected using questionnaires administered to both the CEO and two heads of department in each firm. A total of 549 questionnaires were distributed to the 183 firms, out of which 465 questionnaires were return but only 390 questionnaires for 130 were used for analysis. All these were equivalent to a response rate of $71.04 \%$. The choice of the CEOs was because of the position they hold and extensive knowledge on issues pertaining to the firm. The two heads of department were chosen to assess CEO traits because of their frequent interactions with the CEO and it helped to mitigate the problem of selfreport bias from the CEO (Podsakoff, MacKenzie, Lee, \& Podsakoff, 2003; Waldman, Ramirez, House, \& Puranam, 2001).

\subsection{Reliability and Validity}

The reliability of the instrument was assessed using the Cronbach alpha. The alpha values all for all the variables were all above the recommended value of 0.70 (Sekaran \& Bougie, 2016). Factor analysis was performed to check for construct validity. The analysis showed that firm innovation generated a one-factor solution with an Eigen value of 2.568 and item loadings greater than 0.50 (Hair, Black, Babin, Anderson, \& Tatham, 2006). All independent variables had Eigen values $>1$ and factor loadings were all above 0.50 thus, convergent validity was confirmed (Hair et al., 2006).

\subsection{Measurement of Variables}

Table 1 shows the measures of the variables were measured using five point-Likert scales.

Table-1. Summary of all the measures of the variables.

\begin{tabular}{l|l|l}
\hline Variable & Authors & Five likert scales \\
\hline Firm innovation & (Calantone, Cavusgil, \& Zhao, 2002); (Lin, 2007) & 6 items \\
\hline CEO optimism & (Scheier et al., 1994) -LOT -R test & 6 items \\
\hline CEO humility & (Owens et al., 2013) & 9 items \\
\hline CEO narcissism & (Ames, P., \& Anderson, 2006) & 13 items \\
\hline Firm size & (Jiang, Wang, \& Zhao, 2012) & number of employees \\
\hline Firm age & (Anderson \& Reeb, 2003) & Number of years \\
\hline Firm performance & (Flynn, Huo, \& Zhao, 2010) & 6 items \\
\hline
\end{tabular}

\subsection{Analytical Model Specification}

The study used both descriptive and inferential statistics. Descriptive statistics were used to summarize data and make general observations about the entire data in the study. On the other hand, a multiple regression model was utilized to test and draw conclusions on the hypotheses formulated. Before the analyses of data, the study tested the possibility of violation of multicollinearity assumption using the variance inflation factor and tolerance level. The multiple regression model was expressed as follows:

Where:

$$
F I=\alpha+\beta_{i}(F S)+\beta_{2}(F A)+\beta_{s}(F P)+\beta_{4}(\text { CEOopt })+\beta_{5}(\text { CEOhum })+\beta_{6}(\text { CEOnarc })+\varepsilon
$$

1. FI = Firm Innovation 2. FS = Firm Size 3. FA = Firm Age 4. FP = Financial Performance.

5. CEOopt $=$ CEO optimism 6. CEOhum $=$ CEO humility 7. CEOnarc $=\mathrm{CEO}$ narcissism.

1. $\varepsilon=$ Error term.

\section{Results}

\subsection{Descriptive Statistics}

Table 2 presents the descriptive statistics and correlation analysis. From the results, there is a positive and significant correlation between all the independent variables and firm innovation. Notably, the correlation results revealed that CEO optimism $(r=.677, \rho<.01)$, CEO humility $(r=.296, \rho<.01)$ and CEO narcissism $(r$ $=.567, \rho<.01)$ are all positively and significantly correlated with firm innovation. Hence, it suggests that CEO traits are key factors that may influence firm innovation in financial institutions in Kenya.

\begin{tabular}{|c|c|c|c|c|c|c|c|c|c|}
\hline Variables & 1 & g & 3 & 4 & 5 & c & 7 & Mop & CD \\
\hline Firm innovation & 1 & & & & & & & 3.58 & 0.506 \\
\hline CEO optimism & $.677^{* *}$ & 1 & & & & & & 3.42 & 0.516 \\
\hline CEO humility & $.296^{* *}$ & $.291 * *$ & 1 & & & & & 3.87 & 0.582 \\
\hline CEO narcissism & $.567 * *$ & $.397 * *$ & .026 & 1 & & & & 3.17 & 0.565 \\
\hline Firm size & .109 & .084 & .080 & -.048 & 1 & & & 1.82 & 1.462 \\
\hline Firm age & -.137 & -.022 & -.006 & $-.333^{* *}$ & $.181^{*}$ & 1 & & 2.81 & 0.451 \\
\hline Firm performance & $.239^{* *}$ & -.039 & .054 & $.206^{*}$ & -.088 & $-.206^{*}$ & 1 & 3.75 & 0.699 \\
\hline
\end{tabular}


Regarding the control variables, none of the variables correlates with firm innovation except for financial performance which had a positive and significant association with firm innovation $(r=.239, \rho<.01)$. This suggests that profitable firms are more likely to engage in firm innovation.

\subsection{Hypothesis Testing}

Table 3 shows the regression model that was used to test the hypothesis. The results indicate that the model was significant $(F=33.983, \rho<.01)$ with the combined predictive power of all the predictor variables registering about $62 \%$ of the total variation in firm innovation $\left(R^{2}=.624\right.$, Adjusted $\left.R^{2}=.605\right)$. The results for Hypothesis 1 to 3 were all presented in Table 3. Hypothesis 1 had proposed that CEO optimism would positively affect firm innovation. The results revealed that CEO optimism had a positive and significant effect on firm innovation $(\beta=.502, \rho<.01)$. Thus, the hypothesis was supported. This implies that CEO optimism is a key factor that inspires new innovation. Hypothesis 2 had predicted that CEO humility would enhance firm innovation positively. As displayed in the Table, there was a positive and significant influence between CEO humility and firm innovation $(\beta=.105, \rho<.05)$. So, the hypothesis was accepted. This means a humble CEO has the ability to initiate new innovations. Hypothesis 3 had postulated that CEO narcissism would positively influence firm innovation. As observed in Table 3, the results demonstrate a positive and significant link between CEO narcissism and firm innovation $(\beta=.293, \rho<.01)$. Consequently, the hypothesis was held. This suggests that the more the CEOs become narcissist, the more they contribute to firm innovations.

Table-3. Regression results.

\begin{tabular}{|c|c|c|c|c|c|}
\hline \multirow[b]{2}{*}{ Variable } & \multicolumn{2}{|c|}{$\begin{array}{c}\text { Unstandardized } \\
\text { coefficients }\end{array}$} & \multirow{2}{*}{$\begin{array}{c}\text { Standardized } \\
\text { coefficients }\end{array}$} & \multicolumn{2}{|c|}{ Collinearity statistics } \\
\hline & B & Std. Error & & Tolerance & VIF \\
\hline (Constant) & -.082 & .379 & & & \\
\hline \multicolumn{6}{|l|}{ Control variables } \\
\hline Firm size & .030 & .020 & .088 & .953 & 1.049 \\
\hline Firm age & .009 & .068 & .008 & .837 & 1.194 \\
\hline Financial performance & $.141^{*}$ & .042 & .195 & .913 & 1.095 \\
\hline \multicolumn{6}{|l|}{ Predictor variables } \\
\hline CEO optimism & $.502^{* *}$ & .063 & .513 & .732 & 1.365 \\
\hline CEO humility & $.105^{*}$ & .051 & .121 & .894 & 1.119 \\
\hline $\mathrm{CEO}$ narcissism & $.293^{* *}$ & .059 & .327 & .701 & 1.426 \\
\hline \multicolumn{6}{|l|}{ Model summary } \\
\hline$R$ & \multicolumn{2}{|c|}{.790} & & & \\
\hline$R^{2}$ & \multicolumn{2}{|c|}{.624} & & & \\
\hline Adjusted $R^{2}$ & \multicolumn{2}{|c|}{.605} & & & \\
\hline$R^{2}$ change & \multicolumn{2}{|c|}{.624} & & & \\
\hline$F$ change & \multicolumn{2}{|c|}{$33.983^{*} *$} & & & \\
\hline
\end{tabular}

\section{Discussion and Conclusion}

Responding to the growing interest in CEO traits, this study examined how CEO optimism, humility and narcissism affect firm outcomes such as innovation among financial firms in an emerging economy like Kenya. By incorporating the upper echelons theory and optimism theory we find that indeed CEO traits influence firm innovation. This study found that all the predictor variables are positively related to innovation. In particular, the findings indicate that in the Kenyan context, traits of the CEO are key in strategic decision making. Notably, of the variables investigated in the study, CEO optimism stands out as a key factor that drives innovation in most financial institutions in Kenya. First, it was hypothesized that CEO optimism influences firm innovation. The findings are in tandem with scholarly work of Hirshleifer et al. (2012). Galasso and Simcoe (2011) that CEOs who highly optimistic envision greater opportunities for innovation. In other words despite the uncertainties that innovation may pose to most firms, CEOs who are very optimistic are enthusiastic to face such risks and positively expect to succeed in coming with up new innovations. Second, the study hypothesized CEO humility affect firm innovation. Indeed the findings confirmed that humility among CEOs is important for innovation. According to upper echelons theory (Hambrick \& Mason, 1984), humble CEOs are able to process information that is needed for innovation since they have a tendency to recognize the competencies and expertise of others. Though not very significant compared to the other two variables, CEO humility influences innovation. However, our findings do not concur with Zhang et al. (2017) who argued that there is no association between CEO humility and firm innovation. Our argument is that having humble CEOs in financial institutions it is possible to accommodate everyone to be creative and engage in firm innovations. 
Further, the findings indicate that CEO narcissism is crucial trait that significantly influences firm innovation. These results are in agreement with Kashmiri et al. (2017) that CEOs who are narcissistic are able to decisively come up with new innovations. We attribute this positive results to be resulting from the fact that CEOs who are narcissistic tend to be result oriented, have the desire to achieve better results and protect their reputation (Bass \& Steidlmeier, 1999). In contrast, the findings do not agree with Zhang et al. (2017) who proposed that CEO narcissism has no relation with firm innovation. Therefore, in this study it is important for financial institutions in Kenya to have narcissistic CEOs in order to be innovative. Our findings have theoretical and practical implications.

\subsection{Theoretical and Practical Implications}

This study extends upper echelons theory by confirming that important traits of CEOs such as humility and narcissism have inferences for firm outcomes. Although earlier studies have focused on a limited set of CEO traits (Zhang et al., 2017); (Peterson, Galvin, \& Lange, 2012). The findings of this study broaden the understanding of CEO traits by showing that humility and narcissism are associated with firm innovation. More importantly, this study also used the theory of optimism to show how optimistic CEOs play a role in firm innovation. According to this theory, innovation as a strategic function requires an optimistic CEO who epitomizes visionary goals of the firm. Finally, our study extends academic knowledge on the role of CEO traits in influence firm outcomes more so in a developing economy.

With regard to practical implications, the study suggests that the traits at the CEO level should not be disregarded in strategic decision making especially for firms operating in volatile and turbulent business environment. Therefore the appointing authority specifically the board of financial institutions in Kenya should focus on traits such as optimism, humility, and narcissism when appointing CEOs because firms are likely to be more innovative when such CEOs are at the forefront of corporate leadership.

\section{References}

Ames, D. R., P., R., \& Anderson, C. P. (2006). The npi-16 as a short measure of narcissism. Journal of Research in Personality, $40(4), 440-450$.

Anderson, R. C., \& Reeb, D. M. (2003). Founding-family ownership and firm performance: Evidence from the S\&P 500. The Journal of Finance, 58(3), 1301-1328.

Argandona, A. (2015). Humility in management. Journal of Business Ethics, 132(1), 63-71.

Baregheh, A., Rowley, J., \& Sambrook, S. (2009). Towards a multidisciplinary definition of innovation. Management Decision, 47(8), 1323-1339.

Bass, B. M., \& Steidlmeier, P. (1999). Ethics, character, and authentic transformational leadership behaviour. The Leadership Quarterly, 1O(2), 181-217.

Calantone, R. J., Cavusgil, S. T., \& Zhao, Y. (2002). Learning orientation, firm innovation capability, and firm performance. Industrial Marketing Management, 31(6), 515-524.

Campbell, W. K., Goodie, A. S., \& Foster, J. D. (2004). Narcissism, confidence, and risk attitude. Journal of Behavioral Decision Making, 17(4), 297-311.

Carpenter, M. A., Geletkanycz, M. A., \& Sanders, W. G. (2004). Upper echelons research revisited: Antecedents, elements, and consequences of top management team composition. Journal of Management, 30(6), 749-778.

Carver, C. S., \& Scheier, M. F. (2014). Dispositional optimism. Trends in Cognitive Sciences, 18(6), 293-299.

Chakravarthy, B., \& Yau, D. (2017). Becoming global leaders: Innovation challenges for five large Chinese firms. Strategy E Leadership, 45(2), 19-24.

Chatterjee, A., \& Hambrick, D. C. (2007). It's all about me: Narcissistic chief executive officers and their effects on company strategy and performance. Administrative Science Quarterly, 52(3), 351-386.

Chatterjee, A., \& Hambrick, D. C. (2011). Executive personality, capability cues, and risk taking: How narcissistic ceos react to their successes and stumbles. Administrative Science Quarterly, 56(2), 202-237.

Chen, I.-J., \& Lin, S.-H. (2012). Will managerial optimism affect the investment efficiency of a firm? Procedia Economics and Finance, 2, 73-80.

Chiesi, F., Galli, S., Primi, C., Innocenti, B. P., \& Bonacchi, A. (2013). The accuracy of the life orientation test-revised (lotr) in measuring dispositional optimism: Evidence from item response theory analyses. Journal of Personality Assessment, 95(5), 523-529.

Chipeta, C., \& Muthinja, M. M. (2018). Financial innovations and bank performance in Kenya: Evidence from branchless banking models. South African Journal of Economic and Management Sciences, 21(1), 1-11.

Daily, C. M., Dalton, D. R., \& Cannella, J. A. A. (2003). Corporate governance: Decades of dialogue and data. Academy of Management Revierw, 28(3), 371-382.

Damanpour, F., \& Schneider, M. (2006). Phases of the adoption of innovation in organizations: Effects of environment, organization and top managers. British Journal of Management, 17(3), 215-236.

Davis, D. E., Hook, J. N., Worthington, J. E. L., Van Tongeren, D. R., Gartner, A. L., Jennings, D. J., \& Emmons, R. A. (2011). Relational humility: Conceptualizing and measuring humility as a personality judgment. Journal of Personality Assessment, 93(3), 225-234.

Dobni, C. B., Klassen, M., \& Nelson, W. T. (2015). Innovation strategy in the US: Top executives offer their views. Journal of Business Strategy, 36(1), 3-13.

Dutta, S., Lanvin, B., \& Wunsch-Vincent, S. (2018). The global innovation index, 2018. Ithaca, NY: Cornell, INSEAD, \& WIPO. 
Emmons, R. A. (1987). Narcissism: Theory and measurement. Journal of Personality and Social Psychology, 52(1), 11-17.

Farrington, M. (2012). Does personality matter for small business success? South African Journal of Economic and Management Sciences, 15(4), 381-401.

Finkelstein, S. (1992). Power in top management teams: Dimensions, measurement, and validation. Academy of Management Journal, 35(3), 505-538.

Finkelstein, S., Cannella, S. F. B., Hambrick, D. C., \& Cannella, A. A. (2009). Strategic leadership: Theory and research on executives, top management teams, and boards. USA: Oxford University Press.

Flynn, B. B., Huo, B., \& Zhao, X. (2010). The impact of supply chain integration on performance: A contingency and configuration approach. Journal of Operations Management, 28(1), 58-71.

Friedman, H. H., Fischer, D., \& Schochet, S. (2017). Humility and tone at the top. International Leadership Journal, 9(2), 5479.

Frostenson, M. (2016). Humility in business: A contextual approach. Journal of Business Ethics, 138(1), $91-102$.

Galasso, A., \& Simcoe, T. S. (2011). CEO Overconfidence and innovation. Management Science, 57(8), $1469-1484$.

Germain, M. L. (2018). Narcissism in Leadership and Management: A Research Summary. In Narcissism at Work (pp. 4168). Palgrave Macmillan, Cham.

Gerstner, W.-C., König, A., Enders, A., \& Hambrick, D. C. (2013). CEO Narcissism, audience engagement, and organizational adoption of technological discontinuities. Administrative Science Quarterly, 58(2), $257-291$.

Ghosh, K. (2016). Creative leadership for workplace innovation: An applied sap-lap framework. Development and Learning in Organizations: An International Journal, 30(1), 10-14.

Giorgis Sahile, S. W., Tarus, D. K., \& Cheruiyot, T. K. (2015). Market structure-performance hypothesis in Kenyan banking industry. International Journal of Emerging Markets, 1O(4), 697-710.

Goncalo, J. A., Flynn, F. J., \& Kim, S. H. (2010). Are two narcissists better than one? The link between narcissism, perceived creativity, and creative performance. Personality and Social Psychology Bulletin, 36(11), 1484-1495.

Graham, J. R., Harvey, C. R., \& Puri, M. (2013). Managerial attitudes and corporate actions. Journal of Financial Economics, 109(1), 103-121.

Guedes, M. J. C. (2017). Mirror, mirror on the wall, am I the greatest performer of all? Narcissism and self-reported and objective performance. Personality and Individual Differences, 108(2017), 182-185.

Gupta, A., Nadkarni, S., \& Mariam, M. (2018). Dispositional sources of managerial discretion: CEO ideology, CEO personality, and firm strategies. Administrative Science Quarterly, 1-39.

Gupta, A., \& Spangler, W. D. (2012). The effect of ceo narcissism on firm performance. In: Academy of Management Proceedings. Paper presented at the Academy of Management Briarcliff Manor, NY 10510.

Hackett, R. D., \& Wang, G. (2012). Virtues and leadership: An integrating conceptual framework founded in aristotelian and confucian perspectives on virtues. Management Decision, 50(5), 868-899.

Hair, J. F., Black, W. C., Babin, B. J., Anderson, R. E., \& Tatham, R. L. (2006). Multivariate data analysis. Upper Saddle River, NJ: Pearson Prentice Hall, 6.

Hambrick, D. C., \& Mason, P. A. (1984). Upper echelons: The organization as a reflection of its top managers. Academy of Management Review, 9(2), 193-206.

Hambricks, D. C. (2007). Upper echelons theory: An update. Academy of Management Briarcliff Manor, NY 10510.

Haslam, N. (2007). Sage foundations of psychology series. Introduction to personality and intelligence. Thousand Oaks, CA, US: Sage Publications, Inc.

Hirshleifer, D., Low, A., \& Teoh, S. H. (2012). Are overconfident CEOs better innovators? The Journal of Finance, 67(4), 1457-1498.

Huang-Meier, W., Lambertides, N., \& Steeley, J. M. (2016). Motives for corporate cash holdings: The CEO optimism effect. Review of Quantitative Finance and Accounting, 47(3), 699-732.

Hughes, N., \& Lonie, S. (2007). M-Pesa: Mobile money for the "unbanked" turning cell phones into 24-hour tellers in Kenya. Innovations: Technology, Governance, Globalization, 2(1-2), 63-81.

Islam, E., \& Zein, J. (2019). Inventor CEOs. Journal of Financial Economics. In press, corrected proof, Available online 18 June 2019.

Jack, W., \& Suri, T. (2011). Mobile money: The economics of M-PESA (No. w 16721). National Bureau of Economic Research. Working Paper No. 16721. 1050 Massachusetts Avenue Cambridge, MA 02138.

Jiang, J., Wang, S., \& Zhao, S. (2012). Does HRM facilitate employee creativity and organizational innovation? A study of Chinese firms. The International Journal of Human Resource Management, 23(19), 4025-4047.

Kashmiri, S., Nicol, C. D., \& Arora, S. (2017). Me, myself, and i: Influence of CEO narcissism on firms' innovation strategy and the likelihood of product-harm crises. Journal of the Academy of Marketing Science, 45(5), 633-656.

Langabeer, J. R., \& Yao, E. (2012). The impact of chief executive officer optimism on hospital strategic decision making. Health Care Management Review, 37(4), 310-319.

Lashitew, A. A., Van Tulder, R., \& Liasse, Y. (2019). Mobile phones for financial inclusion: What explains the diffusion of mobile money innovations? Research Policy, 48(5), 1201-1215.

Lepoutre, J., \& Oguntoye, A. (2018). The (non-) emergence of mobile money systems in Sub-Saharan Africa: A comparative multilevel perspective of Kenya and Nigeria. Technological Forecasting and Social Change, 131(2017), $262-275$.

Li, J., \& Tang, Y. (2010). CEO hubris and firm risk taking in China: The moderating role of managerial discretion. Academy of Management Journal, 53(1), 45-68.

Lin, H.-F. (2007). Knowledge sharing and firm innovation capability: An empirical study. International Journal of Manpower, $28(3 / 4), 315-332$.

Malmendier, U., \& Tate, G. (2008). Who makes acquisitions? CEO overconfidence and the market's reaction. Journal of Financial Economics, 89(1), 20-43.

Merton, R. C. (1995). Financial innovation and the management and regulation of financial institutions. Journal of Banking E Finance, 19(3-4), 461-481. 
Morris, J. A., Brotheridge, C. M., \& Urbanski, J. C. (2005). Bringing humility to leadership: Antecedents and consequences of leader humility. Human Relations, 58(10), 1323-1350.

Muthinja, M. M., \& Chipeta, C. (2018). What drives financial innovations in Kenya's commercial banks? An empirical study on firm and macro-level drivers of branchless banking. Journal of African Business, 19(3), 385-408.

Ngugi, B., Pelowski, M., \& Ogembo, J. G. (2010). M-PESA: A case study of the critical early adopters' role in the rapid adoption of mobile money banking in Kenya. The Electronic Journal of Information Systems in Developing Countries $43(1), 1-16$.

Nielsen, R., Marrone, J. A., \& Slay, H. S. (2010). A new look at humility: Exploring the humility concept and its role in socialized charismatic leadership. Journal of Leadership \& Organizational Studies, $17(1)$, 33-43.

Nyukorong, R., \& Quisenberry, W. (2016). Character traits of effective executives: A phenomenological study of CEOs in Ghana. European Scientific Journal, $12(20)$.

Ou, A. Y., Tsui, A. S., Kinicki, A. J., Waldman, D. A., Xiao, Z., \& Song, L. J. (2014). Humble chief executive officers' connections to top management team integration and middle managers' responses. Administrative Science Quarterly, 59(1), 34-72.

Owens, B. P., \& Hekman, D. R. (2012). Modeling how to grow: An inductive examination of humble leader behaviors, contingencies, and outcomes. Academy of Management Journal, 55(4), 787-818.

Owens, B. P., \& Hekman, D. R. (2016). How does leader humility influence team performance? Exploring the mechanisms of contagion and collective promotion focus. Academy of Management Journal, 59(3), 1088-1111.

Owens, B. P., Johnson, M. D., \& Mitchell, T. R. (2013). Expressed humility in organizations: Implications for performance, teams, and leadership. Organization Science, 24(5), 1517-1538.

Peterson, S. J., Galvin, B. M., \& Lange, D. (2012). CEO servant leadership: Exploring executive characteristics and firm performance. Personnel Psychology, 65(3), 565-596.

Peterson, S. J., Walumbwa, F. O., Byron, K., \& Myrowitz, J. (2009). CEO positive psychological traits, transformational leadership, and firm performance in high-technology start-up and established firms. Journal of Management, 35(2), 348-368.

Podsakoff, P. M., MacKenzie, S. B., Lee, J. Y., \& Podsakoff, N. P. (2003). Common method biases in behavioral research: A critical review of the literature and recommended remedies. Journal of Applied Psychology, 88(5), 879-903.

Scheier, M. F., \& Carver, C. S. (1985). Optimism, coping, and health: assessment and implications of generalized outcome expectancies. Health Psychology, 4(3), 219-247.

Scheier, M. F., Carver, C. S., \& Bridges, M. W. (1994). Distinguishing optimism from neuroticism (and trait anxiety, selfmastery, and self-esteem): a reevaluation of the Life Orientation Test. Journal of Personality and Social Psychology, 67(6), 1063-1078

Sekaran, U., \& Bougie, R. (2016). Research methods for business: A skill building approach. Sons: John Wiley.

Smith, M. B., \& Webster, B. D. (2018). Narcissus the innovator? The relationship between grandiose narcissism, innovation, and adaptability. Personality and Individual Differences, 121(2018), 67-73.

Sunder, J., Sunder, S. V., \& Zhang, J. (2017). Pilot ceos and corporate innovation. Journal of Financial Economics, 123(1), 209-224.

Tidd, J., \& Bessant, J. R. (2018). Managing innovation: Integrating technological, market and organizational change: John Wiley $\&$ Sons.

Trevelyan, R. (2008). Optimism, overconfidence and entrepreneurial activity. Management Decision, 46(7), 986-1001.

Vera, D., \& Rodriguez-Lopez, A. (2004). Strategic virtues: Humility as a source of competitive advantage. Organizational Dynamics, 33(4), 393-408.

Waldman, D. A., Ramirez, G. G., House, R. J., \& Puranam, P. (2001). Does leadership matter? CEO leadership attributes and profitability under conditions of perceived environmental uncertainty. Academy of Management Journal, 44(1), 134-143.

Wang, X., \& Dass, M. (2017). Building innovation capability: The role of top management innovativeness and relativeexploration orientation. Journal of Business Research, 76(2017), 127-135.

Wangs, P. (2009). An integrative framework for understanding the innovation ecosystem. Advancing the Study of Innovation and Globalization in Organizations.

Xu, F., Xu, B., Anderson, V., \& Caldwell, C. (2019). Humility as enlightened leadership: A Chinese perspective. Journal of Management Development, 38(3), 158-174.

Yamane, T. (1973). Statistics: an introduction analysis. Harper \& Row. New York: Evanston \& London and John Weather Hill, Inc.

Yar Hamidi, D., \& Gabrielsson, J. (2014). Board chairmanship and innovation in growth oriented firms: Opening up thethe black box of leadershio in the boardroom. In: 14th European Academy of Management EURAM, Universitat de Valencia, Spain, 4-7 June, 2014. European Academy of Management.

Zhang, H., Ou, A. Y., Tsui, A. S., \& Wang, H. (2017). CEO humility, narcissism and firm innovation: A paradox perspective on CEO traits. The Leadership Quarterly, 28(5), 585-604.

Zhou, K. Z., Gao, G. Y., \& Zhao, H. (2017). State ownership and firm innovation in China: An integrated view of institutional and efficiency logics. Administrative Science Quarterly, 62(2), 375-404.

Žiaran, P. (2015). Humility and self-esteem as key predictors of ethical attitude in leadership. Procedia Economics and Finance, 34, 689-696. 